\title{
Survey of pileated gibbon Hylobates pileatus in Thailand: populations threatened by hunting and habitat degradation
}

\author{
RUNGNA PA PHOONJAMPA and WARREN Y. BROCKELMAN
}

\begin{abstract}
Seventeen protected areas in south-east Thailand were surveyed for the Endangered pileated gibbon Hylobates pileatus during April 2004-March 2005, with the objectives of establishing the species' current distribution, obtaining approximate population estimates for the largest forest areas, and assessing threats to the species' survival. Landsat images and a geographical information system were used to identify the remaining suitable habitat within the species' range. We conducted auditory surveys to census the gibbon populations in the five largest protected areas of Khao Yai, Pang Sida, and Tab Lan National Parks, and Khao Soi Dao and Khao Ang Ru Nai Wildlife Sanctuaries. Small protected areas within the range of the pileated gibbon (five parks and seven sanctuaries) were also evaluated, using questionnaires and interviews with local staff and villagers. Approximately $3,800 \mathrm{~km}^{2}$ of suitable canopy forest with an estimated 3,000 breeding groups, containing c. 12,000 individuals, remain within the four largest areas of forest. Pileated gibbons are also still present in 10 of the smaller protected areas. The largest populations of pileated gibbon in Thailand should be viable over the long-term provided that hunting, habitat degradation and further fragmentation are controlled. Hunting is now the most significant problem, and gibbon densities are well below the carrying capacity of the habitat and declining. As patrolling is not sufficiently effective to control poaching, the cooperation and support of local villagers must be sought in future conservation efforts.
\end{abstract}

Keywords Auditory survey, Hylobates pileatus, pileated gibbon, habitat degradation, hunting, population census, Thailand.

Rungnapa Phoonjampa* (Corresponding author) WWF Greater Mekong Thailand Country Programme, 104 Outreach Building, Asian Institute of Technology, Paholyothin Road, Klong Luang, Pathum Thani 12120, Thailand. E-mail rungnapap@wwfgreatermekong.org

WARren Y. Brockelman Department of Biology, Faculty of Science, Mahidol University, Salaya, Phutthamonthon 4 Rd., Nakhon Pathom 73170, Thailand.

${ }^{*}$ Also at: King Mongkut's University of Technology Thonburi, School of Bioresources \& Technology, 83 Moo.8 Thakham, Bangkhuntien, Bangkok 10150, Thailand.

Received 17 February 2007. Revision requested 24 May 2007.

Accepted 20 August 2007.

\section{Introduction}

Thailand has a high biodiversity of fauna and flora that 1 includes four species of gibbons: the white-handed gibbon Hylobates lar, pileated gibbon Hylobates pileatus, agile gibbon Hylobates agilis and siamang Symphalangus syndactylus (Marshall et al., 1972; Brockelman, 1975; Lekagul \& McNeely, 1977; Marshall, 1981; Treesucon \& Tantithadapitak, 1997; Parr, 2003). The pileated gibbon is categorized as Endangered on the IUCN Red List (IUCN, 2007) because of the long-term trend of forest destruction and poaching pressure throughout its range, and it is also on Appendix I of CITES (CITES, 2006). The species is confined to forest areas in south-east Thailand and Cambodia eastward to the Mekong River (Brockelman, 1975; Brockelman \& Gittins, 1984; Marshall \& Sugardjito, 1987). In Thailand the species occurs from the headwaters of the Takhong-Mun River in Khao Yai Park eastward. About two-thirds of the Park's 2,169 $\mathrm{km}^{2}$ lies within its range; the western third is in the range of the white-handed gibbon H. lar (Brockelman \& Gittins, 1984). A few hybrids between these species occur in a restricted area near the river.

A few reports have been published of surveys of pileated gibbons in protected areas of south-east Thailand (Brockelman et al., 1977; Brockelman \& Srikosamatara, 1993) but the only estimates of populations of the species in Thailand are based on extrapolations from a few censused areas, and informed guesses (Brockelman \& Trisurat, 1994; Tilson et al., 1997) that are now out of date. Contemporary and improved estimates of pileated gibbon populations within protected areas (to which the species is now confined) are needed for monitoring current trends and to determine management needs. The aims of this study were to obtain population estimates of pileated gibbons within the largest protected areas overlapping the species' range in Thailand, and to provide field data for the preparation of a national status report and an action plan for conservation of the pileated gibbon.

\section{Methods}

Field surveys were undertaken during April 2004-March 2005 in each of the 18 protected areas within the range of the pileated gibbon (Fig. 1). Virtually no pileated gibbons survive in the wild outside protected areas in Thailand. We used an auditory census (described below) to sample the density of gibbon groups (each containing one mated pair 


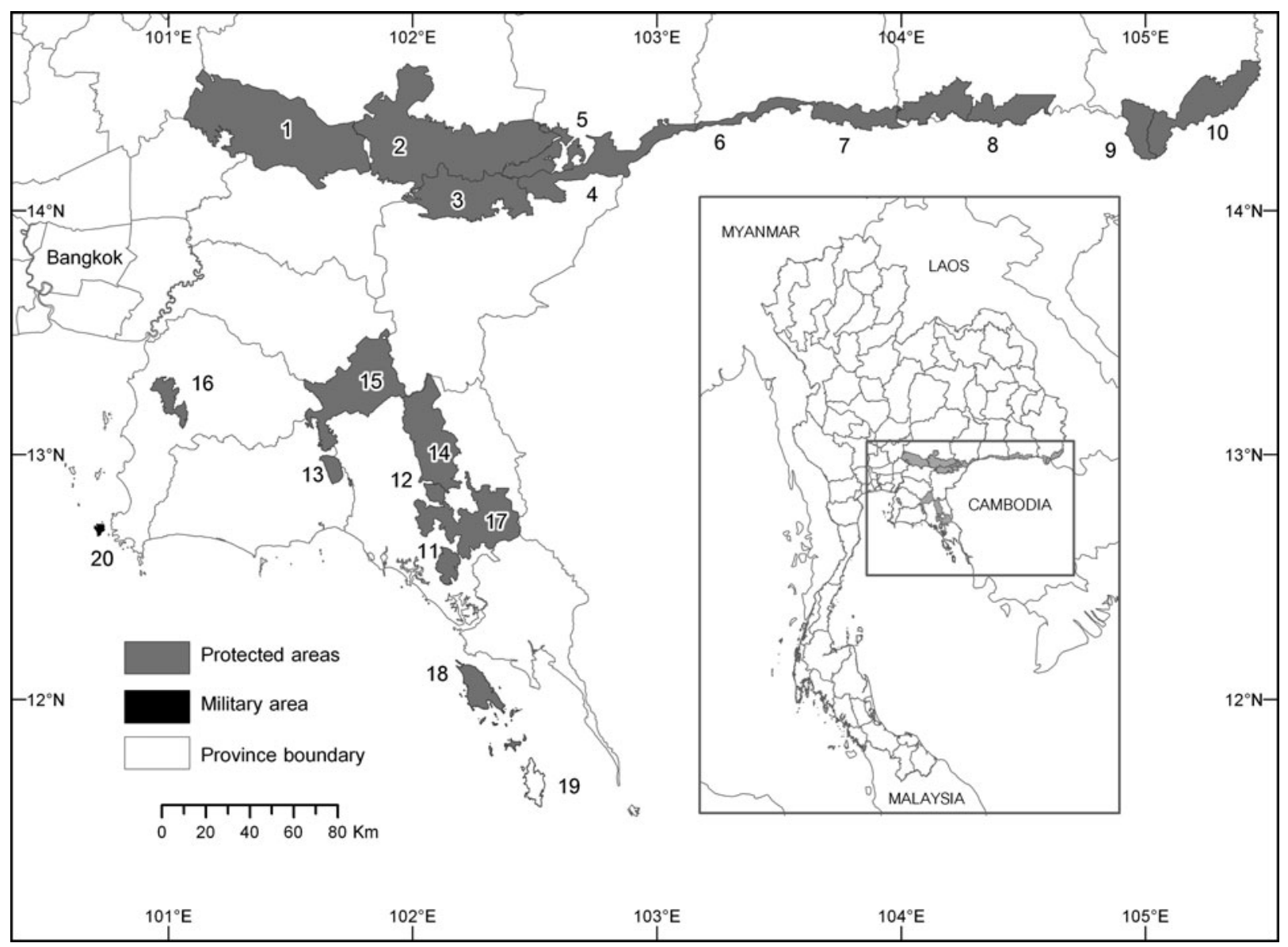

Fig. 1 Protected areas and islands within the range of the pileated gibbon in Thailand: 1, Khao Yai National Park (NP); 2, Tab Lan NP; 3, Pang Sida NP; 4, Tha Phraya NP; 5, Dong Yai Wildlife Sanctuary (WS); 6, Huai Tup Tan-Huai Samran WS; 7, Huai Sala WS; 8, Phanom Dongrak WS; 9, Yot Dom WS; 10, Phu Jong Na Yoi NP; 11, Namtok Phlew NP; 12, Khao Kitchakut NP; 13, Khao ChamaoKhao Wong NP; 14, Khao Soi Dao WS; 15, Khao Ang Ru Nai WS; 16, Khao Khieo-Khao Chomphu WS; 17, Klong Khrua Wai WS; 18, Ko Chang NP; 19, Ko Kut; 20, Ko Khram. Rectangle on the inset indicates the position of the main map in south-east Thailand.

that duets) in the four largest forest areas in south-east Thailand, which contain the five largest protected areas (the smallest is $745 \mathrm{~km}^{2}$ ), including Khao Yai, Pang Sida and contiguous Tab Lan National Parks, and Khao Soi Dao and Khao Ang Ru Nai Wildlife Sanctuaries (Fig. 1). Khao Yai National Park is separated from the nearly-contiguous Tab Lan National Park by a highway and several $\mathrm{km}$ of agricultural area. Evidence of poaching (hunters met, gunshots heard, poachers' camps and cut trees found) was collected in all areas, incidental to the censuses.

In 12 smaller protected areas $\left(58-686 \mathrm{~km}^{2}\right.$ in size; Fig. 1$)$, we spot-checked forest areas to determine the presence of gibbons and interviewed protected area staff at headquarters, rangers at guard posts, and administrative leaders of villages near the forest. Before interviewing villagers we explained the purpose of our survey and obtained their permission. In the interviews data were collected on the precise locations and dates of gibbons recently detected, and local threats to gibbons.

In addition to forest areas on the mainland we visited two large islands off the coast of south-east Thailand,
Ko Chang and Ko Kut (Ko = island; Fig. 1). Ko Chang $\left(650 \mathrm{~km}^{2}\right)$ is the largest island of the Mu Ko Chang Marine National Park and contains $192 \mathrm{~km}^{2}$ of the Park's land area. Ko Kut is a privately owned island of $105 \mathrm{~km}^{2}$.

The auditory census procedure (Brockelman \& Ali, 1987; Brockelman \& Srikosamatara, 1993; Nijman, 2001) involved selecting 4-8 representative census areas widely distributed within each forest complex, and listening for duetted gibbon songs from four listening posts spaced $300-500 \mathrm{~m}$ apart on ridges or hills within each census area. These positions were located using 1:50,000 topographic maps of the Royal Thai Survey Department and, usually, a global positioning system. The listening posts were manned from c. 07.00 until 12.00, the duetting period of pileated gibbons (Brockelman \& Srikosamatara, 1993), on 4 or 5 consecutive days. One or two persons at each post listened for gibbon songs in all directions and recorded the exact starting times of duets and each great-call (the highly distinctive female contribution to the duet) or male solo, along with compass direction and estimated distance. Any call characteristics useful in identifying groups were noted. Weather conditions 
were recorded at 10-minute intervals as sunny, cloudy, rainy, breezy (leaves and small branches rustling), or windy. If pileated gibbons duet on c. $50 \%$ of days in good weather, at least $90 \%$ of groups should be recorded within 4 days of listening (Brockelman \& Srikosamatara, 1993). At least 4 days of good weather (without constant rain or strong wind) were experienced at each site.

Prior to the census work, a 1-week workshop was conducted by WYB to train the survey team in the census methods and to familiarize everyone with the songs of both $H$. pileatus and H. lar, which occurs on the west side of the H. pileatus range in Khao Yai National Park. The auditory census involved a team of 5-6 trained persons who hiked into the census areas and camped near the listening posts. To measure habitat condition at each census area forest canopy cover and mean height were determined from measurements with an optical rangefinder and clinometers from 100 points regularly spaced within a 1-ha area (Brockelman, 1998).

The selection of census areas is critical to the unbiased estimation of average density in the forest area as a whole. Strictly speaking, census areas should be randomly placed but in practice the areas must be readily accessible and contain suitable listening posts and camp-sites. We selected areas on the 1:50,000 scale topographic map that were widely spaced, without any prior knowledge of forest condition or gibbon density. In one case (Khao Soi Dao Wildlife Sanctuary), the census areas tended to be placed in accessible valleys, which may be poached more heavily than the more inaccessible mountain slopes.

Within each census area the density of gibbon groups was estimated by dividing the number of duetting pairs heard during the census period by the listening area. Each day's listening data were plotted on a map of the census area enlarged to a 1:20,000 scale. Duets heard from two or more listening posts could be accurately located by triangulation. The boundary of the listening area around the listening posts was drawn using topographic features such as ridges and hills where possible, otherwise assuming a maximum auditory distance of $2 \mathrm{~km}$. Our experience has shown that pileated gibbon duets can be heard that far under optimal weather conditions if not blocked by terrain features. Areas blocked from the listening posts by terrain, or listening shadows, were excluded from the listening area in each census area. A map of all groups heard was prepared following each listening day.

After combining the gibbon group locations for all days on a single map we were able to estimate conservatively the total number of groups within the listening area. Information useful in determining the total number of groups from all the mapped singing locations includes: their distance apart, whether or not they were ever heard singing at the same time, and individual song characteristics useful in distinguishing groups. Solo song bouts, occasionally given by adult or subadult males, were not included in density estimates, which were based only on the mated pairs (groups) heard.

An approximate estimate of the number of gibbon groups in a protected area or forest area can be obtained by multiplying the average density by the total area of suitable forest habitat. We determined the total area of suitable forest from forest-type maps and land use images from the National Park, Wildlife and Plant Conservation Department, and recent satellite imagery (LANDSAT 7 ETM of March 2003) from the Royal Thai Survey Department. Pileated gibbons occur in canopy evergreen and mixed deciduous-evergreen forest. They have been reported in deciduous forest in northern Cambodia (Traeholt et al., 2005) but in Thailand there is virtually no undisturbed deciduous forest left within the species' range (Brockelman, 1975; Srikosamatara, 1984). The species occurs at altitudes up to c. $1,000 \mathrm{~m}$. The amount of forest area above this altitude in south-east Thailand is negligible.

We attempted to be conservative in estimating available habitat area. We excluded degraded forest and fragmented forest in the periphery of Khao Yai and Tab Lan National Parks, where gibbons experience higher hunting pressure and have lower long-term survival chances.

\section{Results}

\section{Populations in the largest forest areas}

The mean density of gibbon groups in the four largest continuous areas of forest was $0.66-1.03$ groups $\mathrm{km}^{-2}$ (Table 1). The estimated total number of groups ranges

TABLE 1 Summary of surveys for pileated gibbon in the five largest protected areas of south-east Thailand (Fig. 1).

\begin{tabular}{lcccccr}
\hline & $\begin{array}{l}\text { Total } \\
\text { area } \\
\left(\mathrm{km}^{2}\right)\end{array}$ & $\begin{array}{l}\text { Suitable } \\
\text { habitat } \\
\left(\mathrm{km}^{2}\right)\end{array}$ & $\begin{array}{l}\text { No. of census } \\
\text { areas (total LA } \\
\left.\mathrm{km}^{2}\right)\end{array}$ & $\begin{array}{l}\text { Mean } \pm \text { SE } \\
\text { groups km }\end{array}$ & $\begin{array}{l}\text { Total } \\
\text { population } \\
\text { (groups) }\end{array}$ & $\begin{array}{l}\text { Total } \\
\text { population } \\
\text { (individuals) }\end{array}$ \\
\hline Khao Yai National Park & 2,169 & 610 & $5(35)$ & $1.03 \pm 0.394$ & 630 & 2,500 \\
Pang Sida \& Tab Lan National Parks & 3,080 & 1,743 & $8(62)$ & $0.66 \pm 0.176$ & 1,150 & 4,600 \\
Khao Soi Dao Wildlife Sanctuary & 745 & 568 & $4(24)$ & $0.67 \pm 0.259$ & 378 & 1,500 \\
Khao Ang Ru Nai Wildlife Sanctuary & 1,030 & 876 & $4(39)$ & $0.96 \pm 0.260$ & 843 & 3,400 \\
Total & 7,024 & 3,797 & $21(160)$ & $0.81 \pm 0.130$ & 3,002 & 12,000 \\
\hline
\end{tabular}

${ }^{\star} \mathrm{LA}$, listening area 
from 378 (in Khao Soi Dao Wildlife Sanctuary) to 1,150 (in Tab Lan and Pang Sida National Parks). This forested area is actually contiguous with two smaller protected areas, Tha Phraya National Park $\left(594 \mathrm{~km}^{2}\right)$ and Dong Yai Wildlife Sanctuary $\left(313 \mathrm{~km}^{2}\right)$, and the total area of gibbon habitat in this protected area complex is therefore c. $3,900 \mathrm{~km}^{2}$. Some of this forest, however, is bamboo or forest degraded by settlers. Adding these smaller protected areas to this larger forest area would increase the number of groups by at least several hundred but we excluded these areas from the population estimate because we did not census within them. Within Khao Yai National Park the highest density of pileated gibbons was 2.44 groups $\mathrm{km}^{-2}$. This census area is closest to the Park headquarters and relatively far from villages. All other census areas had densities $\leq 1$ group $\mathrm{km}^{-2}$.

Khao Soi Dao Wildlife Sanctuary and the Tab Lan and Pang Sida National Park complex had the lowest densities overall, of 0.6 groups $\mathrm{km}^{-2}$. Khao Ang Ru Nai Wildlife Sanctuary had variable densities, with some areas having $>_{1}$ group $\mathrm{km}^{-2}$. Most of the Sanctuary had been selectively logged before it was gazetted in 1977 (and it was enlarged by nearly $1,000 \%$ in 1992) but many parts have forest in relatively good condition with moderately high gibbon densities. For example, the forest near the Sanctuary headquarters, where we established an intensive gibbon study area in 2006, had a density of 2.2 groups $\mathrm{km}^{-2}$.

Mean group density did not vary significantly among forest areas (Kruskal-Wallis test, $\chi^{2}=1.261, \mathrm{P}=0.738$ ). Therefore it is possible to place approximate confidence limits on the total number of groups in all four major forest areas, i.e. 3,000 $\pm \mathrm{SE} 480$.

To convert the density of groups to a population estimate, the average group size must be known. Average size of pileated gibbon groups in Thailand is 4.0 (range 2-6), based on counts of 33 groups: 14 from Khao Yai National Park (W.Y. Brockelman, unpubl. data), 12 from Khao Soi Dao Wildlife Sanctuary, (Srikosamatara, 1980), and seven from Khao Ang Ru Nai Wildlife Sanctuary (W.Y. Brockelman \& R. Phoonjampa, unpubl. data). These counts of group size do not vary significantly between protected areas or forest types. The total number of individuals in breeding groups in the four largest forest areas, which include five protected areas (Table 1), is thus c. 12,00o, to which could be added c. 1,000 in the two smaller contiguous protected areas (Tha Phraya National Park and Dong Yai Wildlife Sanctuary) that were not censused.

Because the census areas were not selected randomly within the forest areas, the statistical validity of density estimates can be challenged. The listening areas, however, averaged $7.62 \mathrm{~km}^{2}$ in size (range $3.23-14.77, \mathrm{n}=21$ ), and were large enough to contain considerable heterogeneity of terrain and forest condition. They were selected from maps without prior knowledge of forest condition or gibbon presence. Hence we believe that bias in selection is not a serious problem, with the possible exception of Khao Soi Dao Wildlife Sanctuary, as noted in the Methods.

\section{Habitat degradation and poaching}

Analysis of satellite imagery revealed that all four of the large forest areas suffered serious encroachment and degradation before 1990, although agricultural encroachment and logging have been better controlled more recently as boundaries have become better marked and patrolled. Suitable habitat in eastern Khao Yai National Park was calculated to be $610 \mathrm{~km}^{2}$ but c. $50 \%$ of the Park's area within the range of the pileated gibbon is degraded or fragmented. Some areas of dry evergreen forest in the eastern parts of this Park were left out of the area of suitable habitat because they are fragmented and located near villages. These areas still have some gibbons but their survival prospects are poor in the long-term. Within Tab Lan and Pang Sida National Parks the area of suitable habitat was $1,743 \mathrm{~km}^{2}(56.5 \%)$ of $3,080 \mathrm{~km}^{2}$. A considerable amount of bamboo forest in this area was also excluded from area calculations because gibbons do not thrive in it. In Khao Soi Dao Wildlife Sanctuary only $568 \mathrm{~km}^{2}(76 \%)$ of the total area appears suitable for gibbons, and in Khao Ang Ru Nai Wildlife Sanctuary this figure is $85 \%$. Khao Soi Dao and Khao Ang $\mathrm{Ru}$ Nai Wildlife Sanctuaries are connected along several km of their joint border and, in addition, some intact forest outside the protected area system (a military area) adds to the connected area. Thus, these two Sanctuaries are effectively a single forest mass.

The census team found evidence for poaching in all five major protected areas censused and heard gunshots and/or met poachers in 10 out of the 21 census areas. Most of these encounters were in Tab Lan and Pang Sida National Parks. Gibbons, especially duetting, are relatively easy to shoot, although many Thai villagers say they do not hunt these human-like primates. Old poachers' camps were found along streams in several forest areas, and in Khao Yai and Khao Soi Dao the remains of gibbons were found at such camps in earlier surveys (Brockelman et al., 1977; W.Y. Brockelman, unpubl. data). Most of these camps were occupied by groups of eaglewood or aloewood (Aquilaria crassna, Thymelaeaceae) collectors (Srikosamatara \& Brockelman, 2002). In Khao Yai and Pang Sida National Parks cut or scraped Aquilaria trees were found in three of the four census areas. No evidence of Aquilaria tree harvest was seen in Khao Ang Ru Nai Wildlife Sanctuary, and this area also had the least evidence of poachers. The resin-stained wood from wounded Aquilaria trees is carved out and sold to small factories that distil the resin and sell it to traders or manufacturers of pharmaceutical and cosmetic products (Jensen \& Meilby, 2008). 
Resins are harvested from a variety of other forest tree species in the region, and this brings more hunters into the forest. In Khao Soi Dao villagers have permission from the Sanctuary authorities to continue the planting and harvest of ginger Amomum krevanh in large areas of mid-elevation forest, which results in destruction of all tree seedlings, saplings and other ground flora. In these areas most gibbons have been extirpated by poaching.

\section{Smaller protected areas}

Gibbons were found or reported to be present in 10 of the 13 smaller protected areas within the range of $H$. pileatus (Table 2). Apart from Dong Yai Wildlife Sanctuary and Tha Phraya National Park, which are integral parts of the Dong Phraya Yen-Khao Yai Forest Complex, five other areas extend eastward in a strip along the escarpment bordering Cambodia. They have become fragmented and are only weakly connected to one another. In the narrowest protected area, Huai Tup Tan-Huai Samran Wildlife Sanctuary gibbons were extirpated c. 5 years ago (Royal Forest Department, 2003).

The Lam Dom Yai River divides the two easternmost protected areas, Yot Dom Wildlife Sanctuary and Phu Jong $\mathrm{Na}$ Yoi National Park; gibbons are still present in the gallery forest along the river. Land mines are still found along the border with Cambodia, and are an obstacle to wildlife survey and patrolling. Poachers enter the area from across this long border.

Four of the five smaller protected areas in the south-east forest complex still contain gibbons; according to local staff they disappeared from Khao Khieo-Khao Chomphu Wildlife Sanctuary c. 10 years ago. Khong Khrua Wai Wildlife Sanctuary, along the Cambodian border, is relatively large and fragmented but gibbons are still found throughout the area, even near fruit orchards. Khao Kitchakut National Park is separated from Khao Soi Dao Wildlife Sanctuary to

TABLE 2 Occurrence of the pileated gibbon in 13 small protected areas. The numbering refers to that in Fig. 1.

\begin{tabular}{lll}
\hline Protected area* $^{*}$ & Area $\left(\mathrm{km}^{2}\right)$ & Presence \\
\hline 4, Tha Phraya NP & 594 & + \\
5, Dong Yai WS & 313 & + \\
6, Huai Tup Tan-Huai Samran WS & 502 & \\
7, Huai Sala WS & 380 & + \\
8, Phanom Dongrak WS & 316 & + \\
9, Yot Dom WS & 225 & + \\
10, Phu Jong Na Yoi NP & 686 & + \\
11, Namtok Phlew NP & 134 & + \\
12, Khao Kitchakut NP & 58 & + \\
13, Khao Chamao-Khao Wong NP & 84 & + \\
16, Khao Khieo-Khao Chomphu WS & 145 & \\
17, Khlong Khrua Wai WS & 265 & + \\
18, Ko Chang NP & 192 & \\
\hline
\end{tabular}

${ }^{*} \mathrm{NP}$, National Park; WS, Wildlife Sanctuary the north by a forest stream. Khao Chamao-Khao Wong and Namtok Phlew National Parks still have gibbons but these are small, isolated, montane forest fragments, each with $<100 \mathrm{~km}^{2}$ of habitat area.

The islands Ko Chang and Ko Kut have no gibbons, and none were reported by management personnel or residents. We have hiked through the interior forest of both islands and found no evidence that gibbons ever existed there. Ko Chang, with its steep, forest-clad mountainous terrain and permanent streams does, however, appear to be suitable for gibbons. The forest on Ko Kut is of lower stature and has a noticeably lower diversity of tree species.

\section{Discussion}

Of a total of 17 protected areas within the range of the pileated gibbon in Thailand 15 still contain the pileated gibbon but only five protected areas, within four large areas of forest, have populations large enough to ensure their long-term survival. We estimate the total pileated gibbon population in Thailand to be c. 14,000, of which at least 12,000 are included in the four largest contiguous protected area complexes. This is slightly less than half of the total pileated gibbon population of Cambodia, which has been estimated from auditory surveys to be c. 30,000 (Traeholt et al., 2005). Thus Thailand has c. $30 \%$ of the world's population of the species. The population (unsurveyed to our knowledge) in the small portion of Lao PDR west of the Mekong River is probably relatively insignificant by comparison.

It is important, however, to examine the variation in density in these areas and its causes. In Khao Yai National Park the highest density was found in the census area nearest the Park headquarters, where populations of both white-handed and pileated gibbons reach the maximum density of 4-5 groups $\mathrm{km}^{-2}$. These high densities are reached in the moist upland forests of Khao Yai and Khao Soi Dao (Brockelman \& Srikosamatara, 1993; Brockelman et al., 1998). However, it is likely that natural gibbon densities in drier lowland areas and in forest on hill-tops where bamboo is abundant do not exceed 2 groups $\mathrm{km}^{-2}$.

The lowest densities within the largest areas were in Khao Soi Dao Wildlife Sanctuary but these estimates may be below the actual average for the Sanctuary. All census areas were in valleys close to the perimeter. A study in 1978-1979 found group densities on the steep mountains near the centre of the Sanctuary as high as 5 groups $\mathrm{km}^{-2}$, and an average density of groups in several census areas of c. 1.7 groups $\mathrm{km}^{-2}$ (Brockelman \& Srikosamatara, 1993). Further surveys are needed in this area. Khao Soi Dao Wildlife Sanctuary is contiguous along part of its border with Khao Ang Ru Nai Wildlife Sanctuary, which provides a corridor for dispersal. Only Khao Ang Ru Nai Wildlife 
Sanctuary has within it a significant amount of lowland forest $<300 \mathrm{~m}$, whereas most protected areas only contain the forest remaining after all lowland areas have been developed for agriculture.

The densities of gibbons in most of the forest areas, at c. 1 group $\mathrm{km}^{-2}$, appear to be well below the carrying capacity of the forest. The low numbers of groups found in census areas remote from protection units suggest that gibbon densities have been reduced by poaching and are $25-50 \%$ of what they would be in the absence of disturbance. This conclusion is supported by our finding that gibbon density did not correlate with forest canopy cover or average height. Average gibbon densities in the Cardamon Mountains of western Cambodia are also low, largely because of forest fragmentation and hunting pressure (Daltry \& Momberg, 2000; Traeholt et al., 2005). Forests in the Cardamon Range are more moist and species rich than those in Thailand but gibbon densities averaged only c. 1.3 groups $\mathrm{km}^{-2}$ (range 0.31-2.33), reflecting hunting pressure.

The numerous smaller protected areas surveyed have limited conservation value for the pileated gibbon. These areas do, however, have a diversity of plant species and other animals and are important as education and recreation areas. Gibbon populations in some of them may increase if poaching is curtailed. However, the viability of these populations depends primarily on the threats facing them. Even the largest populations are not secure if poaching and habitat loss result in declining trends (Brockelman, 1994). It was for this reason that the primate assessors for the IUCN Red List decided in 2006 to categorize nearly all species of gibbons as Endangered (IUCN, 2007).

We are not aware of any recent or historical records of any species of gibbon on any island off the coast of Thailand. Only Ko Chang appears to have forest habitat suitable for pileated gibbons but they evidently have not survived since the island lost its connection with the mainland. Several other smaller islands off the coast of south-east Thailand have low, less diverse forest affected by salt spray. Among these is Ko Khram, an island of c. $12 \mathrm{~km}^{2}$ that has been suggested as the type locality of $H$. pileatus (Brandon-Jones, 1995). However, there is no firm evidence that the collector, A.H. Mouhot, obtained any gibbons from any island off Thailand; it seems more likely that the Siamese syntype preserved in the Natural History Museum, London, UK, was collected at or near Khao Sabab, where the skin was reported to be cleaned and prepared. This mountain lies within Namtok Phlew National Park (Table 2), which still contains some gibbons. Pileated gibbons were doubtless more abundant there when A.H. Mouhot was collecting in 1859. Landsat images show that destruction of forests in this region and their conversion to agriculture began in the 1960s or shortly before.

On the basis of our study of satellite images, observations in the forest, and survey interviews, it is clear that by the end of the 2oth century hunting had replaced forest destruction as the main threat to the pileated gibbon in Thailand. Most hunting appears to be subsistence hunting by exploiters of minor forest products. The great majority of local villagers appeared to understand conservation problems and the reasons for setting aside protected areas but economic pressures force a minority into the forest to exploit plants and animals.

Thailand's system of National Parks and Wildlife Sanctuaries is growing in popularity with visitors and becoming better managed. Armed rangers are assigned to all areas but with restricted budgets and personnel, protection of these large areas against poachers is virtually impossible. The only solution appears to be to increase the conservation awareness of the villagers living around each area. It would also be highly desirable to reduce the trade in wild aloewood, with its high collateral poaching pressure on a wide variety of mammals and birds. These actions are not, however, the primary mandate of the protected area management authorities. Unless it becomes part of their responsibility, wildlife poaching will continue.

After the surveys were finished we held a meeting and workshop in collaboration with the Department of National Parks, Wildlife and Plant Conservation, and the Faculty of Forestry, Kasetsart University, for the administrative heads of all protected areas in the range of the pileated gibbon. Lectures were given on the ecology of gibbons, and the results of the surveys were presented. A follow-up survey to see what new measures have been implemented is planned.

\section{Acknowledgements}

We give special thanks to Dr. Songtam Suksawang and the superintendents of the 17 protected areas of the National Park, Wildlife and Plant Conservation Department for support and cooperation. For encouragement, valuable guidance, and comments on earlier drafts of this article we would like to give special thanks to John W.K. Parr and Robert Steinmetz. We also thank Sunit Punprom, Naret Seuaturien, Wanlop Chutipong, Niti Sukumal, Daphawan Khamcha, Surasak Srirattanaporn and Siriporn Pornsiritived for their kind support and help throughout the research. We thank all WWF Greater Mekong Thailand Country Programme personnel and National Park, Wildlife and Plant Conservation Department staff. Financial support from the US Fish and Wildlife Service and WWF US is gratefully acknowledged.

\section{References}

Brandon-Jones, D. (1995) Type localities of the gibbon, Hylobates pileatus Gray, 1861, and the leaf monkey, Presbytus crepuscula wroughtoni Elliot, 1909, collected by A.H. Mouhot. International Journal of Primatology, 16, 537-543. 
Brockelman, W.Y. (1975) Gibbon populations and their conservation in Thailand. Natural History Bulletin of the Siam Society, 26, 133-157.

Brockelman, W.Y. (1994) PHVA workshop: learning to help the gibbons of Thailand. Primate Conservation, 15, 58-63.

Brockelman, W.Y. (1998) Study of tropical forest canopy height and cover using a point-intercept method. In Forest Biodiversity Research, Monitoring and Modelling: Conceptual Background and Old World Case Studies. Man and the Biosphere Series, Vol. 20 (eds F. Dallmeier \& J.A. Comiskey), pp. 521-531. UNESCO, Paris, France, and Parthenon Publishing, New York, USA.

Brockelman, W.Y. \& Ali, R. (1987) Method of surveying and sampling forest primate populations. In Primate Conservation in the Tropical Rain Forest (eds C.W. Marsh \& R.A. Mittermeier), pp. 23-62. Alan R. Liss, New York, USA.

Brockelman, W.Y., Damman, D., Thongsuk, P. \& Srikosamatara, S. (1977) Pileated gibbons survey at Khao Soi Dao Sanctuary, Thailand. Tiger Paper, 5, 13-15.

Brockelman, W.Y. \& GitTins, S.P. (1984) Natural hybridization in the Hylobates lar species group: implications for speciation in gibbons. In The Lesser Apes: Evolutionary and Behavioural Biology (eds H. Preuschoft, D.J. Chivers, W.Y. Brockelman \& N. Creel), pp. 498-532. Edinburgh University Press, Edinburgh, UK.

Brockelman, W.Y., Reichard, U., Treesucon, U. \& RAEMAEKERS, J.R. (1998) Dispersal, pair formation and social structure in gibbons (Hylobates lar). Behavioral Ecology and Sociobiology, 42, 329-339.

Brockelman, W.Y. \& Srikosamatara, S. (1993) Estimation of density of gibbon groups by use of loud songs. American Journal of Primatology, 29, 93-108.

Brockelman, W.Y. \& Trisurat, Y. (1994) Thai gibbon habitat and population status. In Thai Gibbon Population and Habitat Viability Analysis (eds S. Tunhikorn, W. Brockelman, R. Tilson, U. Nimmanheminda, P. Ratanaporn, R. Cook et al.), pp. 17-22. IUCN/SSC CBSG report, Apple Valley, USA.

CITES (2006) CITES Appendices I, II, III. Http://www.cites.org [accessed 25 December 2006].

Daltry, J.C. \& Momberg, F. (eds) (200o) Cardamom Mountains Biodiversity Survey 200o. Fauna \& Flora International, Cambridge, UK.

IUCN (2007) 2007 IUCN Red List of Threatened Species. IUCN, Gland, Switzerland. Http//www.iucnredlist.org [accessed 31 March 2008].

Jensen, A. \& Meilby, H. (2008) Does commercialization of a nontimber forest product reduce ecological impact? A case study of the Critically Endangered Aquilaria crassna in Lao PDR. Oryx, 42, 214-221.

Lekagul, B. \& McNeely, J.A. (1977) Mammals of Thailand. Kurusapha Ladprao Press, Bangkok, Thailand.

Marshall, J.T. (1981) The agile gibbon in South Thailand. Natural History Bulletin of the Siam Society, 29, 129-136.

Marshall, J.T., Ross, B.A. \& Chantharojvong, S. (1972) The species of gibbons in Thailand. Journal of Mammalogy, 53, 479486.
Marshall, J. \& Sugardjito, S. (1987) Gibbon systematics. In Comparative Primate Biology, Vol. 1: Systematics, Evolution, and Anatomy (ed. D. Swindler), pp. 137-185. Alan R. Liss, New York, USA.

NiJMAn, V. (2001) Forest (and) primates: conservation and ecology of the endemic primates of Java and Borneo. $\mathrm{PhD}$ thesis, University of Amsterdam, Amsterdam, The Netherlands.

PARR, J.W.K. (2003) A Guide to the Large Mammals of Thailand. Sarakadee Press, Bangkok, Thailand.

Royal Forest Department (2003) Application of Remote Sensing and GIS for Monitoring Forest Land Use Change in Huai Tup Tan-Huai Samran Wildlife Sanctuary. Royal Forest Department, Bangkok, Thailand. [in Thai]

SRIKOSAMATARA, S. (1980) Ecology and behavior of the pileated gibbon (Hylobates pileatus) in Khao Soi Dao Wildlife Sanctuary, Thailand. MSc thesis, Mahidol University, Bangkok, Thailand.

SRIKOSAMATARA, S. (1984) Ecology of the pileated gibbon in southeast Thailand. In The Lesser Apes: Evolutionary and Behavioural Biology (eds H. Preuschoft, D.J. Chivers, W.Y. Brockelman \& N. Creel), pp. 242-257. Edinburgh University Press, Edinburgh, UK.

Srikosamatara, S. \& Brockelman, W.Y. (2002) Conservation of protected areas in Thailand: a diversity of problems, a diversity of solutions. In Making Parks Work: Strategies for Preserving Tropical Nature (eds J. Terborgh, C. van Schaik, L. Davenport \& M. Rao), pp. 218-231. Island Press, Washington, DC, USA.

Tilson, R., Castle, K., Supriatna, J., Gurmaya, K.J., Brockelman, W. \& Tunhikorn, S. (1997) Multi-disciplinary strategic planning for gibbon conservation in Thailand and Indonesia. In Primate Conservation: The Role of Zoological Parks (ed. J. Wallis), pp. 177-197. American Society of Primatologists, USA.

Traeholt, C., Bonthoeun, R., Rawson, B., Samuth, M., Virak, C. \& Vuthin, S. (2005) Status Review of Pileated Gibbon, Hylobates pileatus and Yellow-cheeked Crested Gibbon, Nomascus gabriellae, in Cambodia. Fauna \& Flora International, Phnom Penh, Cambodia.

Treesucon, U. \& Tantithadapitak, T. (1997) Siamang (Hylobates syndactylus): a new mammal recorded for Thailand. Natural History Bulletin of the Siam Society, 45, 123-124.

\section{Biographical sketches}

Rungnapa Phoonjampa leads the pileated gibbon project of the WWF Greater Mekong Thailand Country Programme. She carries out research on habitat use and feeding ecology of the pileated gibbon as a student in the graduate programme of King Mongkut's University of Technology, Bangkhuntien campus, Thailand. WARREN Y. Brockelman has taught in the Faculty of Science, Mahidol University, for over 30 years and has worked on various conservation projects during this time. He conducts long-term research on gibbons and forest ecology in Khao Yai National Park. He is also a research associate at the Thailand National Center for Genetic Engineering and Biotechnology, where he heads the Ecology Laboratory. 